\title{
The Effect of Achievement Motivation and Self Confidence Towards Achievement of Wushu Sanda Athletes
}

\author{
Doris Apriani Ritonga ${ }^{1 *}$, Chairul Azmi ${ }^{1}$, Rima Mediyana Sari ${ }^{1}$ \\ ${ }^{1}$ Faculty of Sport Science, Universitas Negeri Medan, Indonesia \\ *Corresponding author.Email: dorisritonga@gmail.com, chairulazmi58@gmail.com, soberrsoul@gmail.com
}

\begin{abstract}
This study aims to determine the influence of achievement motivation and self-confidence on the achievement of North Sumatra Wushu Sanda Athletes in the North Sumatra Regional Championships. Subjects in this study were Wushu Sanda athletes who participated in the 2017 North Sumatra Regional Championship. The measuring instrument used in this study was the success of athletes reaching the final round, the scale of achievement motivation, and the scale of selfconfidence. Research Hypothesis: There is an influence of achievement motivation and self-confidence on athletes' achievements in the North Sumatra Wushu Sanda Regional Championship. The analysis used logistic regression. The results of the analysis show that the equation model can be accepted with the results of the Hosmer and Lemeshow Test of 0.920 (> 0.05). Nagelkerke R Square statistic of 0.201 shows the ability of achievement motivation and selfconfidence variables to explain athlete achievement by $20.1 \%$. This means that there are other factors that can give more effect on the achievements of Wushu Sanda athletes who were not defined in this study. This might occur because of other psychological aspects that affect the match situation such as emotional regulation, strategy in dealing with opponents, concentration, and others. Thus it is recommended to conduct research with other psychological aspects to see the influence on achievement in the competition.
\end{abstract}

\section{Keywords: Achievement, Achievement Motivation, Self Confidence, Wushu Sanda}

\section{INTRODUCTION}

Law no. 3 of 2005 concerning National Sports System Chapter I Article I No. 17 states that achievement is the result of maximum effort achieved by sportsmen or groups (teams) in sports activities. "defined sports achievement as a collection of results achieved by an athlete in carrying out the tasks assigned to him" [1].

An achievement of an athlete shows his success in mastering the task. When an athlete gains high achievements, he can increase his satisfaction and pride in completing his duties. "Sports is the actualization of the accumulated results of the training process shown by sportsmen in accordance with their abilities, an accomplished athlete shows the success of the training process he has done" [2]. On the contrary, the low achievement of athletes shows the low success of the training process. "The processes and stages of training in a certain period of time are important in fostering athletic performance" [3]. Even if a person has a special talent in a particular field of sport, without targeted training, that talent will remain as a hidden potential. A person's talent or potential needs to be explored and trained specifically to be directed in an effort to gain achievement. Exploring potential and practicing it in a directed manner is a continuous learning process from initial preparation to the peak of achievement.
The peak achievement of an athlete can be gained because of three important factors that need to be considered, namely 1) The athlete's physical factors, which are related to prime physical condition as an important asset an athlete must have in order to show maximum performance with endurance, speed, flexibility, agility, motion coordination, and strength that supports both training and competition; 2) Technical factors, which relate to specific skills in accordance with the motives of the sports activities involved, 3) Psychological factors, namely the structure and function of the psychic aspects of the athlete both in terms of character and cognitive that can support the actualization of potential athletes. These three factors support each other to optimally produce the achievements of the athletes. "This is based on the characteristics of athletes as humans who have psychosomatic unity, namely the unity of the soul and body, one with the other affects each other" [4]. "The psychological problems faced by athletes are often related to problems of technical ability and physical abilities" [5]. For example, routine physical exercise and demands for mastery of certain techniques can be stressors that have an impact on the motivation of an athlete. "Excessive anxiety during the game results in the obstruction of the athlete from showing his best performance" [6].

On the contrary, some psychological sources that support someone in gaining achievement will encourage 
the athlete to be better prepared to perform tasks according to their abilities. The athlete will be able to overcome unfavorable situations in either training or competition. One of the psychological aspects that support achievement is achievement motivation. "showed that there was a significant positive relationship of 0.701 between achievement motivation and achievement of athletes" [7]. That is, high achievement motivation will further support the achievement of the athlete.

Achievement motivation is motivation that aims to gain recognition or avoid failure and relate to performance in situations that apply standards of excellence to oneself and to others. As a manifestation of achievement motivation, a person will show hard working behavior, in a way that is most likely to regularly handle ideas objectively and independently, reflecting the mobilization of energy in achieving its goals. "This shows an effort to strive for success, survive when facing failure, improve performance and skills to achieve desired goals" [8]. In this study, achievement motivation is a behavior that reflects energy mobilization. This energy directs a person to achieve his goals in the most possible way through hard work and ability in handling certain ideas and things in an orderly, objective, and independent manner.

Some things affect the high and low achievement motivation of an athlete in undergoing training and competition programs, as happened to Wushu Sanda athletes in Medan, North Sumatra. This can be seen from the unstable presence of athletes in the training program scheduled by the coach. Some athletes joined training regularly only before the competition began.

There are several reasons that decrease athletes motivation to take part in an exercise program. Among them are boredom in training routines, exhausting training programs, and temptation of other more interesting activities. These things can certainly affect the performance of athletes in gaining achievement.

To understand achievement motivation, it is necessary to know some factors that can influence it. Some of these factors are physical and mental health, a healthy and pleasant environment, sports that fit with athletes talents and instincts, arrangement of interesting training activities, audio-visual aids, and training methods.

In addition, other psychological aspects that influence achievement are self-confidence. "self-efficacy is an assessment of how well a person can show a behavior needed to overcome a particular situation or task. In the world of sports the term self-efficacy is better known as sport confidence, that is, individual beliefs about their ability to succeed in sports" [9].

Aspects of self-confidence in the world of sports showed a significant relationship between self-confidence and the achievements of Tae Kwon Do athletes in Yogyakarta. An athlete who has good self-confidence will be able to show sports performance as expected.

They are the belief that he has the expertise and physical skills needed to achieve success; the belief that he is able to focus, maintain concentration, and make decisions to achieve success; and the belief that he is able to refocus after making a mistake and immediately rose after a bad performance, and overcome doubts and problems to achieve success.

After examining the influence of achievement motivation and confidence in achievement, this study aims to determine the influence of achievement motivation and self-confidence on the achievements of Wushu Sanda athletes who take part in the 2017 North Sumatra Regional Championship.

\section{SUBJECT AND METHOD}

\subsection{Sample and Population}

The sample of this study was 113 Wushu Sanda athletes who participated in the North Sumatra Regional championship, consisting of 75 athletes from the Junior group and 38 athletes from the Senior group. Of the 113 questionnaires distributed, only 102 questionnaires were returned. The total number of questionnaires returned consisted of 72 questionnaires from the junior boys and girls group, 30 questionnaires from the senior male and female groups.

The characteristics of the study sample were 1) Wushu Sanda athletes who had previously passed selections in their respective regions to take part in the 2017 North Sumatra Regional Championship; 2) Wushu Sanda athletes who had participated in training in their respective regions for at least 1 year, assuming they had already known the condition of training and competition.

Based on all questionnaire data that were successfully collected, the distribution of population data and samples can be seen in the following table:

Table 1: Construction of population data and samples.

\begin{tabular}{|c|r|r|r|}
\hline $\begin{array}{c}\text { Age } \\
\text { Group }\end{array}$ & $\begin{array}{c}\text { Reac } \\
\text { hing } \\
\text { Final }\end{array}$ & $\begin{array}{c}\text { Not } \\
\text { Reaching } \\
\text { Final }\end{array}$ & Total \\
\hline Junior & 41 & 31 & 72 \\
\hline Senior & 23 & 7 & 30 \\
\hline Total & 64 & 38 & 102 \\
\hline
\end{tabular}

The sampling technique uses total sampling technique. 64 athletes reach the final round. 38 athletes did not reach the final round. The total sampling were 102 athletes.

\subsection{Research Design}

The purpose of this study is to see the influence of 2 independent variables on 1 dependent variable.

The dependent variable of this study is the achievement of the athlete. In this study, the athlete's achievement is the result of the athlete's effort to reach the final after successfully defeating an opponent in the previous round.

The independent variables of this study are achievement motivation and self-confidence. The operational definition of achievement motivation in this study is a behavior that reflects the mobilization of energy that directs a person to achieve his goals in the most possible way through hard work and the ability to handle certain ideas and things in an orderly, objective, and independent manner. 
The operational definition of self-confidence in this study is the athlete's belief in his ability to obtain the skills and physical skills needed to achieve success; his ability to focus, maintain concentration, and make decisions to achieve success; and his ability to refocus after making a mistake and immediately get up after a bad performance and eliminate doubts about mistakes and decreased performance.

\subsection{Data Collection}

Achievement motivation was measured using the AMS questionnaire (Achievement Motivation Scale) which was adapted from Establishing an Achievement Motivation Scale for the Sport for all.

Self-confidence was measured using a self-confidence questionnaire adapted from SSCI (Sport States Confidence Inventory) developed by

Achievements were measured based on data from the results of the 2017 North Sumatra regional championship, namely the athletes who had succeeded in reaching the final round (winning first, second and third place).

\section{RESULT}

\subsection{Data Exploration}

Based on the descriptive analysis results, the description of the data can be seen in the following table:

Table 2: The Description of Data Sample.

\begin{tabular}{|c|c|c|c|c|c|}
\hline Variable & Mean & Median & SD & Min & Max \\
\hline $\begin{array}{c}\text { Achievement } \\
\text { Motivation }\end{array}$ & 36,35 & 36,00 & 4,77 & 21 & 48 \\
\hline $\begin{array}{c}\text { Self- } \\
\text { Confidence }\end{array}$ & 77,26 & 79,00 & 16,286 & 39 & 116 \\
\hline
\end{tabular}

\subsection{Normality Test}

To assess the distribution of data in groups or variables, the normality test was carried out using the Kolmogorov-Smirnov statistic.

Hypothesis testing:

H0 : the data of achievement motivation/ self-confidence/ Achievements of athletes with normal distribution

H1 : the data of achievement motivation/ self-confidence/ Achievements of athletes with abnormal distribution.

Decision-making criteria: $\mathrm{HO}$ is rejected if p-value $<0.05$, then the sample achievement motivation / selfconfidence / achievement comes from a population with an abnormal distribution.

Table 3: Normality Test.

\begin{tabular}{|c|c|c|}
\hline Variable & $\mathrm{P}$ & Decision \\
\hline $\begin{array}{c}\text { Achievement } \\
\text { Motivation }\end{array}$ & 0,016 & Abnormal \\
\hline Self-Confidence & 0,200 & Normal \\
\hline Achievement & 0,000 & Abnormal \\
\hline
\end{tabular}

Based on table 3, it is known that the distribution of data with achievement motivation has a p-value of 0.016
$(<0.05)$, the achievement motivation is abnormally distributed. The self-confidence variable with $\mathrm{p}$-value 0.200 (>0.05), the distribution of self-confidence data is normally distributed, and the achievement variable has a pvalue of $0,000(<0,05)$ then the achievement is abnormally distributed.

\subsection{Data Scale}

The scale of this research data consisted of ordinal data and nominal data. The scale of data retrieval for achievement motivation variables was the ordinal scale with the category of Strong and Sufficient. The scale of data collection for the self-confidence variable was the ordinal scale with High and Moderate categories. While the scale of data collection for athlete achievement variables was the nominal scale or non metric category, with Accomplished if he reached the final round and Not Yet Accomplished if he did not reach the final round.

Categorization of research variables were based on the description of research empirical data. The scale of the research data and categorization can be seen in the following table:

Table 4: The Scale of Research Data.

\begin{tabular}{|c|c|c|c|}
\hline Variable & $\begin{array}{c}\text { The Scale of } \\
\text { Data } \\
\text { Collection }\end{array}$ & $\begin{array}{c}\text { The Category } \\
\text { of Data } \\
\text { Grouping }\end{array}$ & Koding \\
\hline $\begin{array}{l}\text { Achieve- } \\
\text { ment } \\
\text { Motivation } \\
\text { (with } \\
\text { median) }\end{array}$ & $\begin{array}{c}\text { ordinal } \\
\text { (category) }\end{array}$ & $\begin{array}{c}\text { Sufficient if } \\
\text { the total score } \\
<36 \\
\text { Strong if the } \\
\text { total score } \geq \\
36\end{array}$ & $\begin{array}{c}1= \\
\text { Strong } \\
2= \\
\text { Sufficient }\end{array}$ \\
\hline $\begin{array}{c}\text { Self- } \\
\text { Confidence } \\
\text { (with mean) }\end{array}$ & $\begin{array}{c}\text { ordinal } \\
\text { (category) }\end{array}$ & $\begin{array}{c}\text { Moderate if } \\
\text { the total score } \\
<\text { mean } \\
\text { High if the } \\
\text { total score } \geq \\
\text { mean }\end{array}$ & $\begin{array}{c}1= \\
\text { High } \\
\\
2= \\
\text { Moderate }\end{array}$ \\
\hline $\begin{array}{l}\text { Athlete } \\
\text { Achieve- } \\
\text { ment }\end{array}$ & $\begin{array}{c}\text { Nominal } \\
\text { (category- } \\
\text { non metric) }\end{array}$ & $\begin{array}{l}\text { Accomplishe } \\
\mathbf{d} \\
\text { if reaching the } \\
\text { final round } \\
\text { Not Yet } \\
\text { Accomplished } \\
\text { if not reaching } \\
\text { the final round }\end{array}$ & $\begin{array}{c}1= \\
\text { Accomplis } \\
\text { hed } \\
\text { (reaching } \\
\text { final) } \\
0= \\
\text { Not Yet } \\
\text { Accomplis } \\
\text { hed (not } \\
\text { reaching } \\
\text { final) }\end{array}$ \\
\hline
\end{tabular}

\subsection{The Description of the Data Analysis Result}

Based on the results of data processing, an overview of the distribution of research variables was obtained as follows: 
Table 5. The Distribution of Achievement Motivation Frequency.

\begin{tabular}{|c|c|c|}
\hline Category & F & $\%$ \\
\hline Strong & 64 & 62,7 \\
\hline Sufficient & 38 & 37,3 \\
\hline Total & 102 & 100,0 \\
\hline
\end{tabular}

Table 6. The Distribution of Self-Confidence Frequency.

\begin{tabular}{|c|c|c|}
\hline Category & F & $\%$ \\
\hline High & 43 & 42,2 \\
\hline Moderate & 59 & 37,3 \\
\hline Total & 102 & 100,0 \\
\hline
\end{tabular}

Table 7. The Distribution of Athlete Achievement Frequency.

\begin{tabular}{|c|c|c|}
\hline Category & F & $\%$ \\
\hline Accomplished & 64 & 62,7 \\
\hline $\begin{array}{c}\text { Not Yet } \\
\text { Accomplished }\end{array}$ & 38 & 37,3 \\
\hline Total & 102 & 100,0 \\
\hline
\end{tabular}

To find out correlation between the independent variable and the dependent variable, the researchers used Chi-Square test because the variables of achievement of the athletes had a nominal scale while the variables of achievement motivation and self-confidence had ordinal scale.

\section{Hypothesis testing:}

$\mathrm{H} 0$ : there is a correlation between achievement motivation and self-confidence with athlete's achievements.

H1: there is no correlation between achievement motivation and self-confidence with athlete's achievements.

Decision criteria:

$\mathrm{HO}$ is rejected if $\mathrm{p}$-value $\leq 0.05$, so there is no correlation between achievement motivation and selfconfidence with athlete's achievements. H0 is accepted if p-value> 0.05 , so there is a correlation between achievement motivation and confidence with athlete's performance.

Fisher Exact Test which stated the correlation between achievement motivation and athlete achievement used $2 \times 2$ tables. The results showed that some athletes who had strong achievement motivation became accomplished athletes (reaching the final round), as many as 39 athletes (38.2\%); and most of the athletes who had sufficient achievement motivation became accomplished athletes (reaching the final round), as many as 25 athletes (24.5\%).

The Fisher Exact Test result obtained a $p$ value of 0.392 (>0.05) so that $\mathrm{H} 0$ was accepted. This means that correlation between achievement motivation and the achievements of Wushu Sanda athletes at the North Sumatra Regional Championship was not significant.

The results showed that most athletes who had high self-confidence became accomplished athletes (reaching the final round), as many as 36 athletes (35.3\%); and most athletes who had moderate self-confidence became athletes without achievements (not reaching the final round), as many as 31 athletes $(30.4 \%)$. The Fisher Exact test results obtained $\mathrm{p}$ value of $0,000(<0.05)$ so that $\mathrm{H} 0$ was rejected. This means correlation between selfconfidence and the achievements of the Wushu Sanda athletes at the North Sumatra Regional Championship was very significant.

To determine the influence of achievement motivation and self-confidence on athlete's achievement, researchers used logistic regression model because the variable of athlete's achievement is a categorical data which is dichotomic and has an abnormal distribution.

The model of logistic regression equation used in this study is:

$$
\begin{aligned}
& \operatorname{Ln}(\text { pres } / 1-\text { pres })=\alpha i+\beta 1 X 1+\beta 2 X 2 \\
& + \text { eit }
\end{aligned}
$$

Explanation:

pres $=$ accomplished $=$ reaching final probabiliy

$\mathrm{X}_{1}=$ the variable of achievement motivation

$\mathrm{X}_{2}=$ the variable of self-confidence

To see whether the empirical data matches the model so that the model can be said to be fit, simultaneous testing was carried out to find the compatibility or feasibility of the overall regression model. In this case, the Hosmer and Lemeshow Test was used with the following criteria:

a. If the value of Hosmer and Lemeshow is $\leq 0.05$, it means that there is a significant difference between the model and the observation so that goodness fit is not good, because the model cannot predict the value of the observations.

b. If the value of Hosmer and Lemeshow is > 0.05, it means that the model is able to predict the value of its observations or it can be said that the model is acceptable because it matches the observational data.

Table 8. Hosmer and Lemeshow Test.

\begin{tabular}{|c|c|c|c|}
\hline Step & $\begin{array}{c}\text { Chi- } \\
\text { square }\end{array}$ & df & Sig. \\
\hline 1 & 0,168 & 2 & 0,920 \\
\hline
\end{tabular}

Table 8 shows that the chi-square value is 0.168 with significance (p-value) of 0.920 . Based on these results, because the significance value is greater than 0.05 , it can be concluded that the model is able to predict the value of its observations or in other words, the model can be accepted because it matches the observations data.

Hypothesis Testing in this study was carried out partially.

Testing Hipothesis:

a. Odds ratio $(\mathrm{OR})>1$ : This shows that these variables are risk factors for the occurrence of certain effects.

b. Odds ratio $(\mathrm{OR})<1$ : This shows that the variable is a protective factor which means reducing the incidence of effects. 
Table 9. The Interpretation of Odds Ratio (OR) Coefisien.

\begin{tabular}{|c|c|c|}
\hline $\begin{array}{c}\text { Protective Factor } \\
(\mathrm{OR})\end{array}$ & $\begin{array}{c}\text { Risk Factor } \\
(\mathrm{OR})\end{array}$ & Interpretation \\
\hline 1 & 1 & No Correlation \\
\hline $0,67<\mathrm{OR}<1$ & $1<\mathrm{OR}<1,5$ & $\begin{array}{c}\text { Weak } \\
\text { Correlation }\end{array}$ \\
\hline $0,33<\mathrm{OR}<0,67$ & $1,5<\mathrm{OR}<3$ & $\begin{array}{c}\text { Moderate } \\
\text { Correlation }\end{array}$ \\
\hline $0,1<\mathrm{OR}<0,33$ & $3<\mathrm{OR}<10$ & $\begin{array}{c}\text { Strong } \\
\text { Correlation }\end{array}$ \\
\hline $\mathrm{OR} \leq 0,1$ & $\mathrm{OR} \geq 10$ & $\begin{array}{c}\text { Very Strong } \\
\text { Correlation }\end{array}$ \\
\hline
\end{tabular}

Table 10. Partial Effect Test of the Predictor Variable.

\begin{tabular}{|c|c|c|c|c|}
\hline $\begin{array}{c}\text { Predictor } \\
\text { Variable }\end{array}$ & $\mathrm{B}$ & OR & Sig. & $\begin{array}{c}\text { Explanatio } \\
\mathrm{n}\end{array}$ \\
\hline $\begin{array}{c}\text { Achievement } \\
\text { Motivation }\end{array}$ & 0,559 & 1,749 & 0,235 & $\begin{array}{c}\text { Not } \\
\text { significant }\end{array}$ \\
\hline $\begin{array}{c}\text { Self- } \\
\text { Confidence }\end{array}$ & $-1,852$ & 0,157 & 0,000 & $\begin{array}{c}\text { Very } \\
\text { significant }\end{array}$ \\
\hline Konstanta & 2,795 & $\begin{array}{c}16,36 \\
7\end{array}$ & 0,004 & $\begin{array}{c}\text { Very } \\
\text { significant }\end{array}$ \\
\hline
\end{tabular}

Table 10 showed the influence of predictor variables, namely achievement motivation and self-confidence on athlete achievement variables. The sample test results showed that at a significance level $(\alpha)$ of $5 \%$, achievement motivation had no significant effect on athlete achievement with $\mathrm{p}=0.235$ (>0.05) and self-confidence variables had a very significant effect on athlete's achievement with $\mathrm{p}=0,000$ (> 0.05). Odds Ratio (OR) scores for the achievement motivation variables were 1,749 times $(\approx 1,75)$ indicating that the achievement motivation had a probability of 1,749 times $(\approx 1,75)$ causing athletes to have achievements (reaching the final round) and the self-confidence variables having an OR value of $0.157(\approx 0.16)$ shows that self-confidence had a probability of $0.157(\approx 0.16)$ times causing athletes to have achievement (reaching the final round). This shows that achievement motivation has a stronger influence on athlete's achievement than self-confidence.

Achievement motivation acts as a risk factor, which influences athletes to reach the final. The Variable of selfconfidence with an OR value of 0.16 has a strong influence on the achievement of the athlete. Selfconfidence acts as a protective factor, which reduces the influence of athlete's achievements in reaching the final.

The coefficient of determination is used to find out how big the dependent variability is. The coefficient of determination in logistic regression can be seen in Nagelkerke R Square. The Nagelkerke R Square value of 0.201 indicated that the ability of achievement motivation variable and self-confidence variable affected athletes' achievement by $20.1 \%$. This means that there are other factors as much as $79.9 \%$ which have more influence on the achievements of Wushu Sanda athletes at the North Sumatra Regional Championship and they were not defined in this study. The model which is developed by using the achievement motivation variable and the confidence variable to predict athlete's achievement is $\mathrm{Y}=2,795+0,559$ Achievement Motivation $-1,852$ Self-Confidence.

This shows that increasing achievement motivation provides a great opportunity for athletes to reach the final (get achievement), while self-confidence tends to protect athletes to reach the final (get achievement). The results also showed that the value of the Risk Ratio (RR) for Sufficient Achievement Motivation and Moderate SelfConfidence is 0.5521 . This means that athletes who possess sufficient achievement motivation and moderate self-confidence have the opportunity to get achievement (reaching final round) as much as $55.21 \%$. The Risk Ratio (RR) for strong achievement motivation and moderate self-confidence is 0.4134 . This means that athletes who obtain strong achievement motivation and moderate selfconfidence have the opportunity to get achievement (reaching final round) as much as $41.34 \%$. The Risk Ratio (RR) for sufficient achievement motivation and high selfconfidence is 0.8870 . This means that athletes who obtain sufficient achievement motivation and high selfconfidence have the opportunity to get achievement (reaching final round) as much as $88.70 \%$. The Risk Ratio (RR) for strong achievement motivation and high selfconfidence is 0.8179 . This means that athletes who obtain strong achievement motivation and high self-confidence have the opportunity to get achievement (reaching final round) as much as $81.79 \%$.

Finally, "The availability of quality human resources who have excellent physical, mental and social conditions and mastery of science and technology are indicators of the success of a nation's development"[10].

\section{CONCLUSIONS}

This study aims to determine the influence of achievement motivation and self-confidence on the achievements of Wushu Sanda athletes in the 2017 North Sumatra Regional Championship. After carrying out statistical tests with logistic regression, it was found that the Nagelkerke R Square value of 0.201 showed the ability of achievement motivation variables and self-confidence variables which explained the athlete's achievements by $20.1 \%$, while the remaining $79.9 \%$ was explained by other variables outside the research model. This may occur because of other psychological aspects that affect the competition such as regulation of emotions, strategies to face opponents, concentration, and others. Thus, it is recommended to conduct research related to psychological aspects other than achievement motivation and selfconfidence to see their influence on athlete's achievements in the competition.

\section{REFERENCES}

[1] Adisasmito, Lilik. " Mental Juara Modal Atlet Berprestasi”. Jakarta: Rajagrafindo Persada. 2007. pp. 12 
[2] Sukadiyanto. "Pengantar Teori dan Metodologi Melatih Fisik". Bandung: CV. Lubuk Agung. 2011. pp. 22.

[3] Satiadarma. "Pengamalan Prinsip Belajar dalam Menyusun Program Pembinaan Prestasi Olahraga". In Singgih D. Gunarsa, Monty P. Satiadarma, \& M.H. Soekasah, Psikologi Olahraga: Teori dan Praktik. Jakarta: PT. BPK Gunung Mulia. 1996. pp. 19-45.

[4] B. Rushall. "Mental Skills Training for Sport. A. Manual for Athletes, Coaches, and Sport Psychologist". San Diego: San Diego State University. 1992. pp. 41

[5] Harsono. "Aspek-aspek Psikologi dalam Latihan. In Singgih D. Gunarsa., M.P. Satiadara., \& M/H/ Soekasah. Psikologi Olahraga: Teori dan Praktik". Jakarta: PT. BPK Gunung Mulia. 1996. pp. 46-72

[6] Hasibuan. “ Hubungan antara Kecemasan dan Agresivitas dengan Prestasi Olahraga Beladiri Tarung Derajat pada Atlet Petarung Putra". Surakarta: Tesis. Fakultas Ilmu Keolahragaan Universitas Negeri Surakarta. 2010. pp.34

[7] Rohmat. "Hubungan Motivasi Berprestasi dengan Pencapaian Prestasi Loncat Indah Atlet Porda XI Jawa Barat". Bandung: Skripsi. Fakultas Pendididkan Olahraga dan Kesehatan, Universitas Pendidikan Indonesia. 2013. pp.19

[8] S. Rea. "Sport Science, A Complete Introduction". Great Britain: An Hachette UK Company. 2015. pp. 26

[9] Juriana. "Peran Pelatihan Mental dalam Meningkatkan Kepercayaan Diri Atlet Renang Sekolah Ragunan”. Depok: Tesis. Fakultas Psikologi Universitas indonesia. 2012. pp. 76

[10] Z. Zulbahri, "Tingkat Kemampuan Daya Tahan Jantung dan Pernafasan Mahasiswa Pendidikan Olahraga dan Kesehatan Universitas Pasir Pengaraian", Gelanggang Olahraga: Jurnal Pendidikan Jasmani dan Olahraga, vol. 3, no. 1, pp. 96-101, Oct. 2019. 